\title{
Effect of oestrogen on pregnancy of guinea-pigs
}

\author{
J. J. Evans, Iris L. Sin, Anne Y. Merrick and P. R. Kelleher \\ Department of Obstetrics \& Gynaecology, Christchurch Women's Hospital, Christchurch, \\ New Zealand
}

\begin{abstract}
Summary. Pregnant guinea-pigs were injected with oestrogen at different stages of gestation. After injections on Days 17 and 18 and on Days 25, 26, 32 and 33 peripheral maternal progesterone concentrations were lower than in control animals. Histology showed deleterious changes in the corpora lutea. After injections on Days 10 and 11 the maternal progesterone concentrations remained in the normal range for some time in 12 of 16 guinea-pigs and the corpora lutea appeared histologically normal. Oestrogen therefore affects the pregnancy differently at different stages of gestation.
\end{abstract}

\section{Introduction}

During pregnancy of the guinea-pig, progesterone is first synthesized by corpora lutea with extended life-spans and later by the placenta (Heap \& Deanesly, 1966). However, the factors involved in maintaining pregnancy are little understood. The involvement of an anti-luteolysin in the maintenance of the corpora lutea has been proposed (Bland \& Donovan, 1969; Maule Walker \& Poyser, 1974). Blatchley, Maule Walker \& Poyser (1975) suggested that inhibition of oestradiol release early in pregnancy may be important. The present investigation was performed to investigate the sensitivity of pregnant guinea-pigs to oestrogen administered at different stages of gestation.

\section{Materials and Methods}

Female guinea-pigs were mated at oestrus during the cycle or post partum. Vaginal membranes were observed daily and the day on which a vaginal plug was observed was taken as the day of mating (Day 1). Pregnancy was subsequently confirmed when possible by continued closure of the membrane and high serum progesterone concentrations.

Pregnant animals were injected subcutaneously with $100 \mu \mathrm{g}$ oestradiol-17 $\beta$ (Sigma Chemical Co, St Louis, U.S.A.) alone or with $1 \mathrm{mg}$ progesterone (Sigma Chemical Co, St Louis, U.S.A.) in $1 \mathrm{ml}$ of a mixture of paraffin oil $(0.85 \mathrm{ml})$ and mannide monoleate $(0.15 \mathrm{ml})$. Oestradiol benzoate (Paines \& Byrne Ltd, Greenford, England) was given as a dose of 10 or $100 \mu \mathrm{g}$ in 0.5 $\mathrm{ml}$ arachis oil. The 7 animals in Group 1 were injected on Days $25,26,32$ and 33 post coitum (p.c.), and 4 received oestradiol alone while 3 received oestradiol and progesterone. The animals in Group $2(\mathrm{~N}=15)$ were injected on Days 17 and 18 p.c., and the 16 in Group 3 were injected on Days 10 and 11 p.c. Each treatment was given to 3 or 4 animals in Groups 2 and 3. Maternal peripheral progesterone concentrations were monitored until after the pregnancies ended at term or by abortion.

The animals were bled weekly under light halothane anaesthesia by heart puncture $(2 \mathrm{ml})$. Serum was collected and progesterone concentrations were measured by radioimmunoassay. 
The radioimmunoassay used an antiserum (kindly donated by Professor J. T. France, Auckland) raised in rabbits against progesterone-11-hemisuccinate-BSA, which was specific to progesterone. The antiserum had the following \% reactivities: progesterone, 100 ; testosterone, $0 \cdot 16$; cortisone, 0.007; oestriol, <0.001; oestrone, <0.001; androstenedione, 0.14 ; oestradiol-17 $\beta$, 0.01 ; cortisol, 0.006 ; pregnenolone, $0.001 ; 17 \alpha$-hydroxyprogesterone, 0.26 ; corticosterone, $0.69 ; 4$-pregnen-20 $\alpha$-ol-3-one, 2.04 . The assay involved extracting 10 or $50 \mu 1$ serum with $4 \mathrm{ml}$ ether and transferring $1 \mathrm{ml}$ of the ether phase to each of two test tubes. The ether was evaporated and $0.3 \mathrm{ml}$ antiserum and tritiated progesterone were added. Antibody-bound and free fractions were separated with dextran-coated charcoal. The method provided quantitative recoveries and had a sensitivity of $5 \mathrm{ng} / \mathrm{ml}$. The intra-assay coefficient of variation was $6.0 \%$ and the inter-assay coefficient of variation was $8 \cdot 7-13 \cdot 2 \%$ using plasma controls and extracted progesterone standards. The normal range of progesterone concentrations during pregnancy was established by sampling untreated animals.

Ovaries for histological examination were removed from animals injected with $100 \mu \mathrm{g}$ oestradiol or $100 \mu \mathrm{g}$ oestradiol benzoate and fixed in $10 \%$ formalin or Bouin's fluid and embedded in paraffin wax. Sections were stained with haematoxylin and eosin or Masson's blue. Maximum luteal cell size was estimated by assuming that the cells were ovoid with two diameters being two-thirds of the maximum observed diameter. Statistical comparison of luteal cell size was carried out by using Student's $t$ test. Five animals injected on Days 25, 26, 32 and 33 p.c. were killed on Days 37-39 p.c., 4 injected on Days 17 and 18 p.c. were killed on Day 21 p.c. and of 5 injected on Days 10 and 11 p.c. 3 were killed on Day 14 p.c. and 2 were killed on Day 21 p.c.

\section{Results}

As shown in Text-fig. 1, there was a rapid rise in progesterone concentration after Day 15, and peak values were obtained at about Day 40 . The amount of progesterone in the maternal serum did not appear to be related to the number of fetuses present: 7 animals bled at Days 37-39, carrying 2-7 fetuses, had serum progesterone concentrations of 224-768 $\mu \mathrm{g} / \mathrm{l}$, representing 55-313 $\mu \mathrm{g}$ progesterone/1 for each fetus. Individual animals bled weekly throughout pregnancy

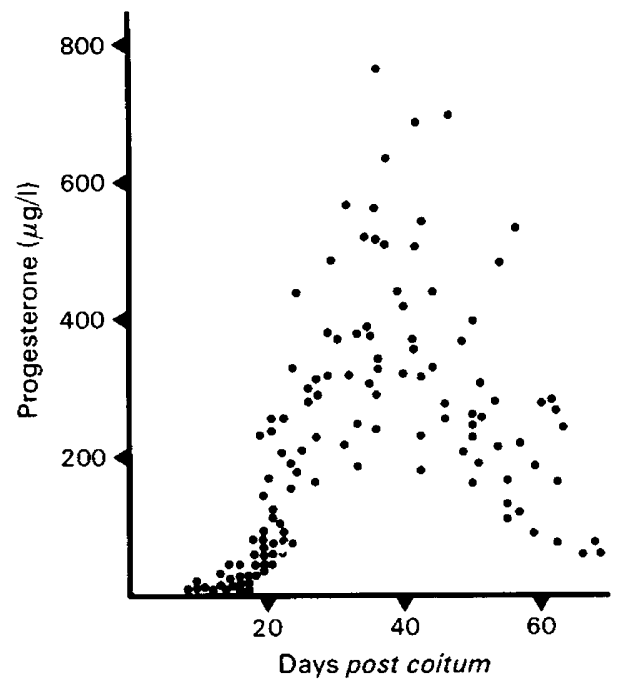

Text-fig. 1. The concentration of progesterone in the maternal serum of 34 guinea-pigs during pregnancy. 
displayed a two-phase profile of serum progesterone (Text-fig. 2) with a peak between Days 30 and 40, and a second peak or shoulder between Days 45 and 55. Guinea-pigs injected with oil medium had progesterone concentrations in the range found in uninjected animals.

\section{Group 1}

Progesterone levels in the females in Group 1 were lower than in normal animals (Text-fig. 3). Three of the animals injected with $100 \mu \mathrm{g}$ oestradiol subsequently aborted, the fourth produced 2 live offspring and 2 small dead fetuses at Day 69. Two of the 3 guinea-pigs given oestradiol and progesterone also aborted; the other produced 3 live offspring after 71 days of gestation. The progesterone concentrations of the 2 females which remained pregnant were within the normal range at the end of the pregnancy.

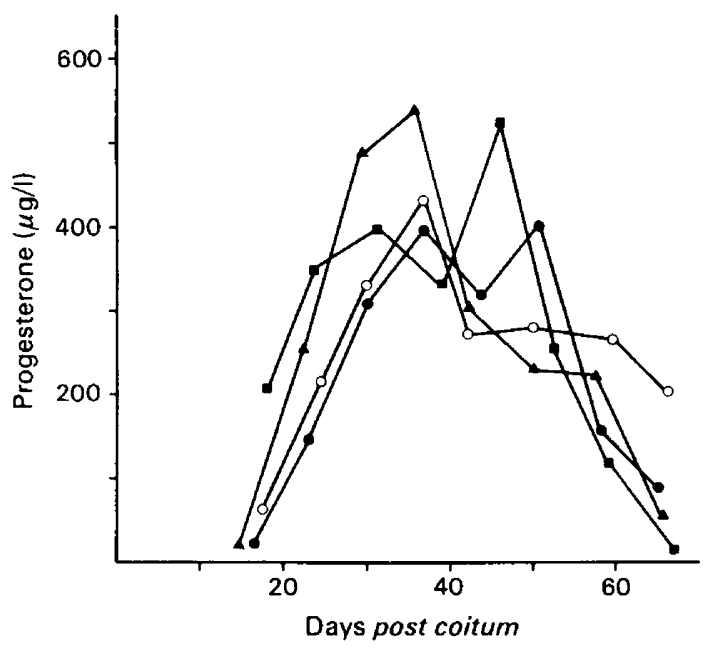

Text-fig. 2. Serum progesterone in 4 pregnant guinea-pigs, demonstrating the biphasic pattern of progesterone concentrations.

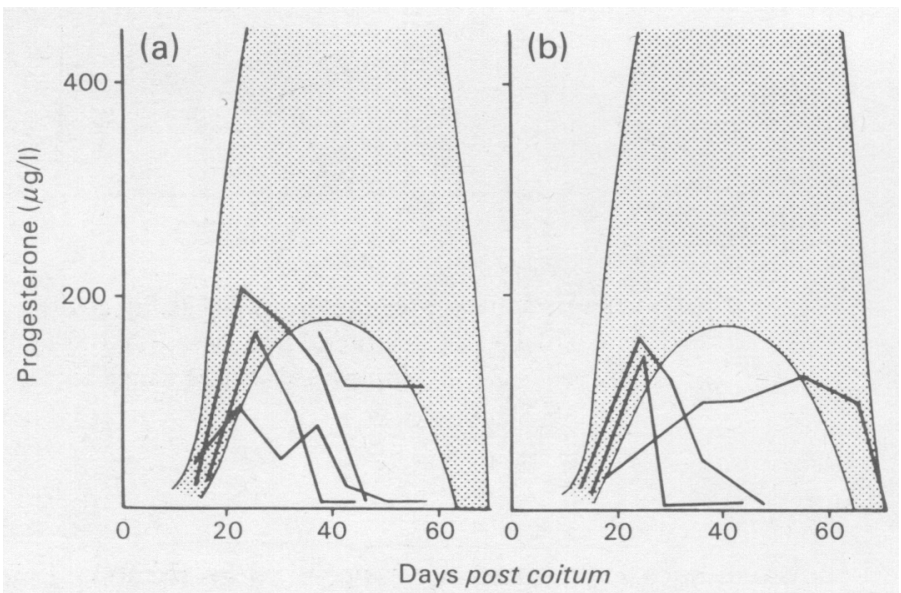

Text-fig. 3. Serum progesterone concentrations in pregnant guinea-pigs injected on Days 25,26 , 32 and 33 with (a) $100 \mu \mathrm{g}$ oestradiol or (b) $100 \mu \mathrm{g}$ oestradiol $+1 \mathrm{mg}$ progesterone. The stippled area is the range of concentrations in normal guinea-pigs (see Text-fig. 1). 
Histological examination of the corpora lutea from oestradiol-injected guinea-pigs showed that there was a decrease in luteal cell size by Day 37, from $4.00 \pm 0.32 \times 10^{3} \mu^{3}$ (mean \pm s.e.m.) in normal animals to $2.80 \pm 0.24 \times 10^{3} \mu \mathrm{m}^{3}(P<0.001)$. There were more pycnotic nuclei in the luteal cells of treated animals than in those of normal animals (PI. 1, Figs 1 and 2).

\section{Group 2}

All injections given on Days 17 and 18 resulted in a reduction in maternal progesterone levels (Text-fig. 4) and abortion occurred in all animals within 20 days, but usually much sooner.

The luteal cells of guinea-pigs killed on Day 21 had volumes of $2.16 \pm 0.16 \times 10^{3} \mu^{3}$, compared to $3.36 \pm 0.40 \times 10^{3} \mu \mathrm{m}^{3}(P<0.01)$ in controls, and there was an increased number of pycnotic nuclei. An increase in the number of endothelial cells was also observed in corpora lutea from treated animals (Pl. 1, Figs 3 and 4).

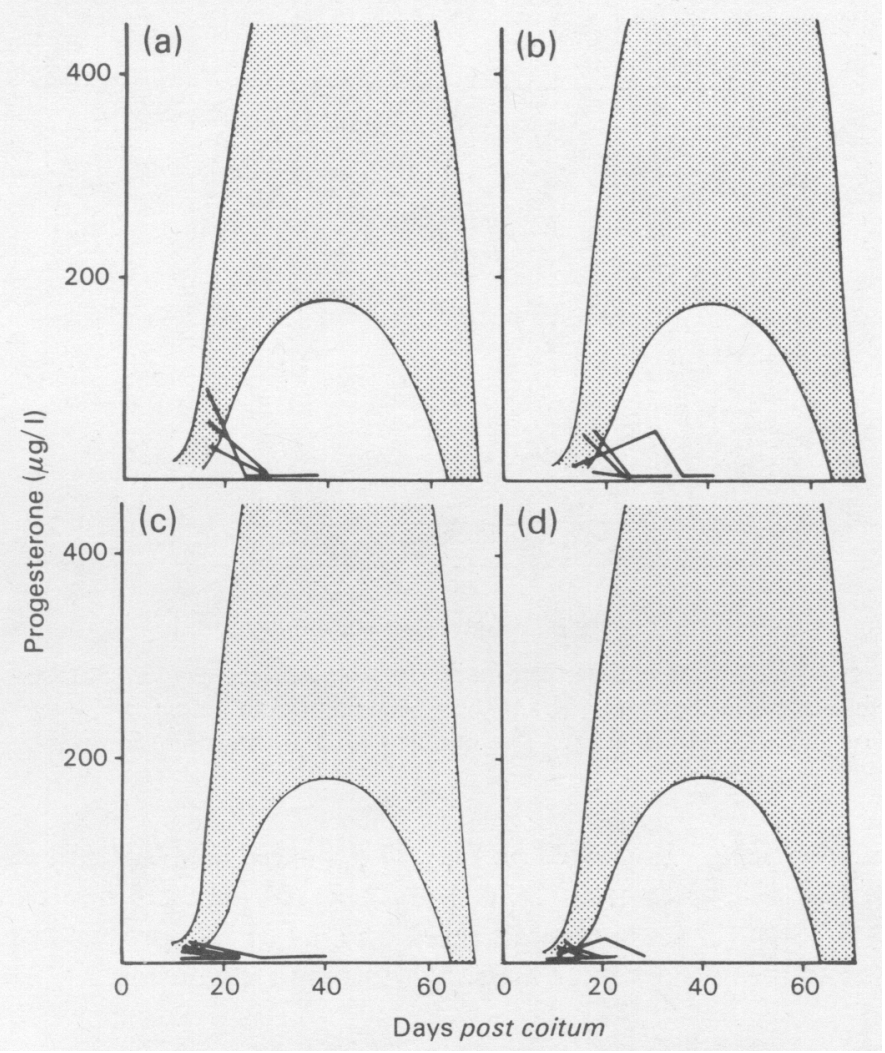

Text-fig. 4. Serum progesterone concentrations in pregnant guinea-pigs injected on Days 17 and 18 with (a) $10 \mu \mathrm{g}$ oestradiol benzoate, (b) $100 \mu \mathrm{g}$ oestradiol benzoate, (c) $100 \mu \mathrm{g}$ oestradiol, or (d) $100 \mu \mathrm{g}$ oestradiol $+1 \mathrm{mg}$ progesterone. The stippled area is the range for normal animals (see Text-fig. 1).

\section{Group 3}

Most of these animals had normal progesterone concentrations for some time after treatment (Text-fig. 5). Two guinea-pigs ( 1 given $10 \mu \mathrm{g}$ oestradiol benzoate and 1 given oestradiol and progesterone) carried their pregnancies to term and gave birth to 4 live offspring and 3 offspring, at different stages of development, that did not survive, respectively. One animal given $100 \mu \mathrm{g}$ 
oestradiol died at Day 42 apparently from toxaemia after death of the 6 fetuses in utero. Other animals had reduced progesterone concentrations and aborted between Days 30 and 50 . There did not seem to be any marked differences in response to the injections of different oestrogens.

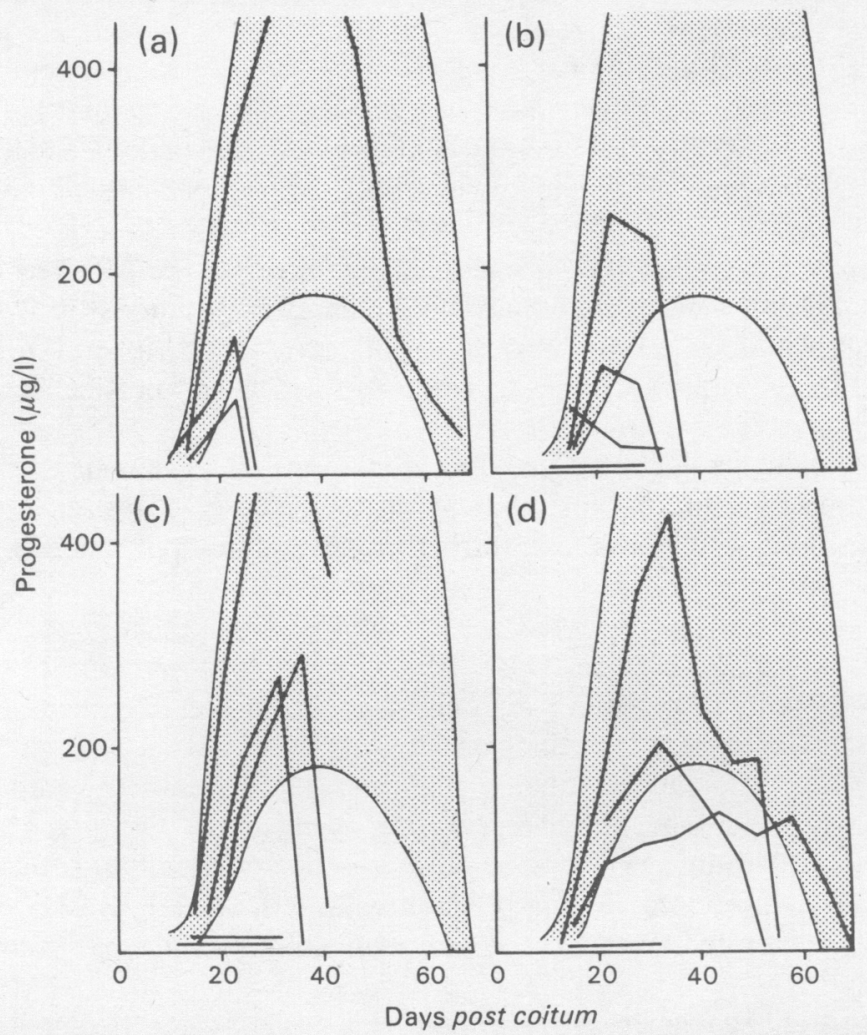

Text-fig. 5. Serum progesterone concentrations in pregnant guinea-pigs injected on Days 10 and 11 with (a) $10 \mu \mathrm{g}$ oestradiol benzoate, (b) $100 \mu \mathrm{g}$ oestradiol benzoate, (c) $100 \mu \mathrm{g}$ oestriol, or (d) $100 \mu \mathrm{g}$ oestradiol $+1 \mathrm{mg}$ progesterone. The stippled area is the range for normal animals (see Text-fig. 1).

The corpora lutea of the animals killed on Day 14 appeared histologically normal (PI. 1, Figs 5 and 6). Controls had cell volumes of $2.56 \pm 0.22 \times 10^{3} \mu^{3}$ and treated animals had cell volumes of $2.88 \pm 0.18 \times 10^{3} \mu \mathrm{m}^{3}$. Animals killed on Day 21 had progesterone concentrations in the normal range and the corpora lutea appeared histologically normal.

\section{Discussion}

The serum progesterone concentrations in normal pregnancy in guinea-pigs were similar to those observed by Challis, Heap \& Illingworth (1971). The rapid rise in progesterone concentrations between Days 15 and 25 has been shown to be related to a reduction in metabolic clearance rate (Challis et al., 1971).

During pregnancy corpora lutea grow for 18-20 days and the size is maintained until parturition, although degenerative changes are apparent after Day 35 (Rowlands, 1956). Although luteal progesterone content remains constant during pregnancy (Rowlands \& Short, 1959), Heap \& Deanesly (1966) suggested that there was some change in secretion or release of 
the steroid in the second half of pregnancy. Placental progesterone production probably begins at about Days 20-25 (Tam, 1977) but becomes significant, relative to luteal production, only at later stages of gestation. The biphasic pattern in individual progesterone levels was possibly a result of reduction in progesterone secretion by the corpora lutea, followed by an increased output by the placenta (Heap \& Deanesly, 1966). Deanesly (1963) found that exogenous progesterone permitted fetal development at least up to Day 20 in ovariectomized guinea-pigs, but the continuation of pregnancy was not investigated. It is possible that the administration of oestrogen on Days 10 and 11 in the present study, in which abortions occurred after Day 25, interfered with some aspect of development whose effects became apparent only at later gestation.

Luteal, as opposed to placental, progesterone seemed to be affected by the oestrogen injections because the most dramatic effects were seen after injections on Days 17 and 18. At this time the placenta does not contribute significantly to peripheral progesterone levels. However, the possibility remains that oestrogen might act as an abortifacient on the conceptus and luteal decline is a secondary effect.

There were no readily apparent differences in response in injections of different oestrogen doses. Administration of $1 \mathrm{mg}$ progesterone at the same time as oestrogen did not appear to improve fetal survival markedly, although further progesterone supplements might possibly have had a significant effect.

The present results indicate that the sensitivity to oestrogen changes during pregnancy. When oestrogen was administered on Days 10 and 11 normal amounts of progesterone were observed for some time in 12 out of 16 animals. The corpora lutea appeared normal 3 and 10 days after treatment. In contrast, injections on Days 17 and 18 invariably caused a reduction of progesterone levels and termination of the pregnancies. Histologically the corpora lutea had been affected by oestrogen treatment within a few days of injection. Oestrogen administration on Days 25, 26, 32 and 33 resulted in lowered progesterone concentrations, but these did not fall immediately to the levels found in non-pregnant animals (Feder, Resko \& Goy, 1968). If corpora lutea had degenerated but the placenta continued to produce progesterone such a result would be expected.

The basis for this change in sensitivity with gestation is not clear. Illingworth \& Perry (1973) demonstrated that, with regard to luteal sensitivity to oestrogen, the age of a corpus luteum in non-pregnant animals was not a central factor but that pituitary and/or uterine controls were possibly important. Placental contribution to luteal maintenance must also be considered. If an 11-12-day embryo, but not a 9-10-day embryo, is transplanted to a normal guinea-pig, then oestrus is delayed (Bland \& Donovan, 1969), suggesting that a placental anti-luteolysin acts between Days 12 and 25 of pregnancy to maintain corpora lutea. In the present study the pregnancies were less sensitive to oestrogen at Days 10 and 11 than at Days 17 and 18. It is possible, therefore, that the corpora lutea of pregnancy and the cycle are differently sensitive to oestrogen-induced regression or that more than one factor is involved.

\section{PLATE 1}

Corpora lutea of pregnant guinea-pigs. Haematoxylin and eosin, $\times 65$.

Fig. 1. At Day 37, normal pregnancy.

Fig. 2. At Day 37 after injection of $100 \mu$ gestradiol benzoate on Days $25,26,32$ and 33 of pregnancy.

Fig. 3. At Day 21, normal pregnancy.

Fig. 4. At Day 21 after injection of $100 \mu \mathrm{g}$ oestradiol benzoate on Days 17 and 18 of pregnancy.

Fig. 5. At Day 14, normal pregnancy.

Fig. 6. At Day 14 after injection of $100 \mu$ g oestradiol benzoate on Days 10 and 11 of pregnancy. 


\section{PLATE}
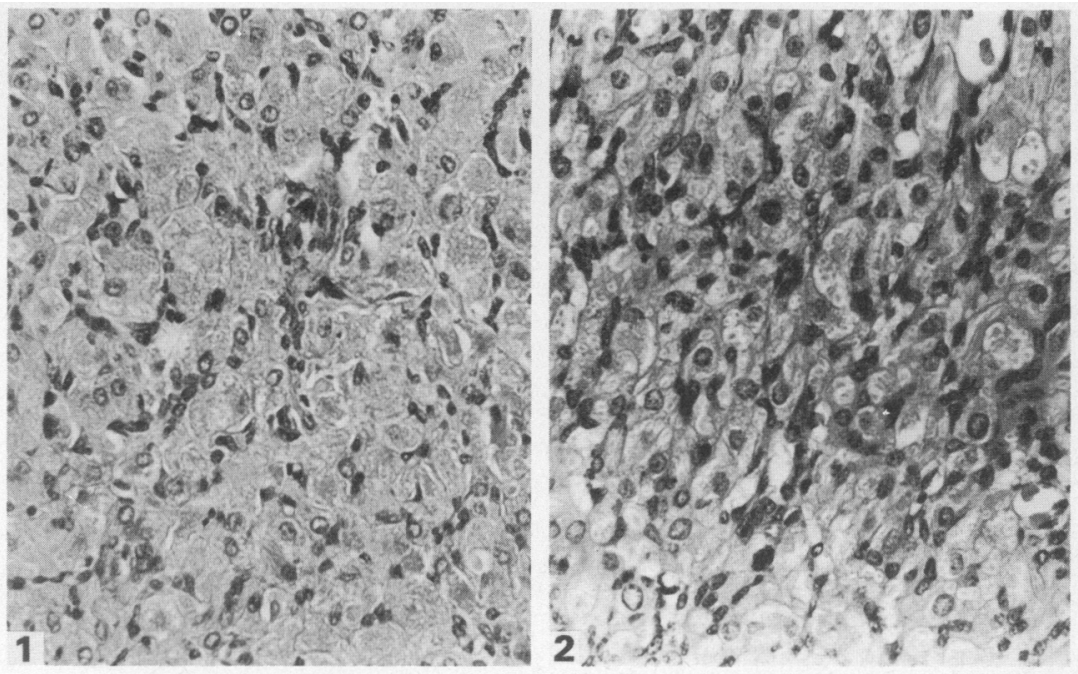

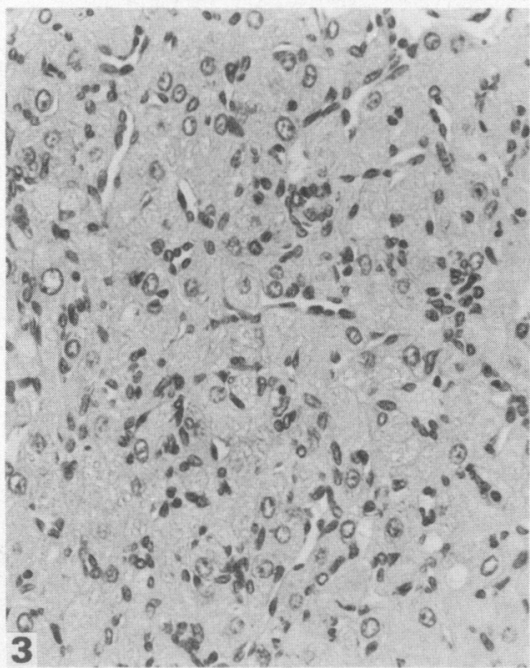
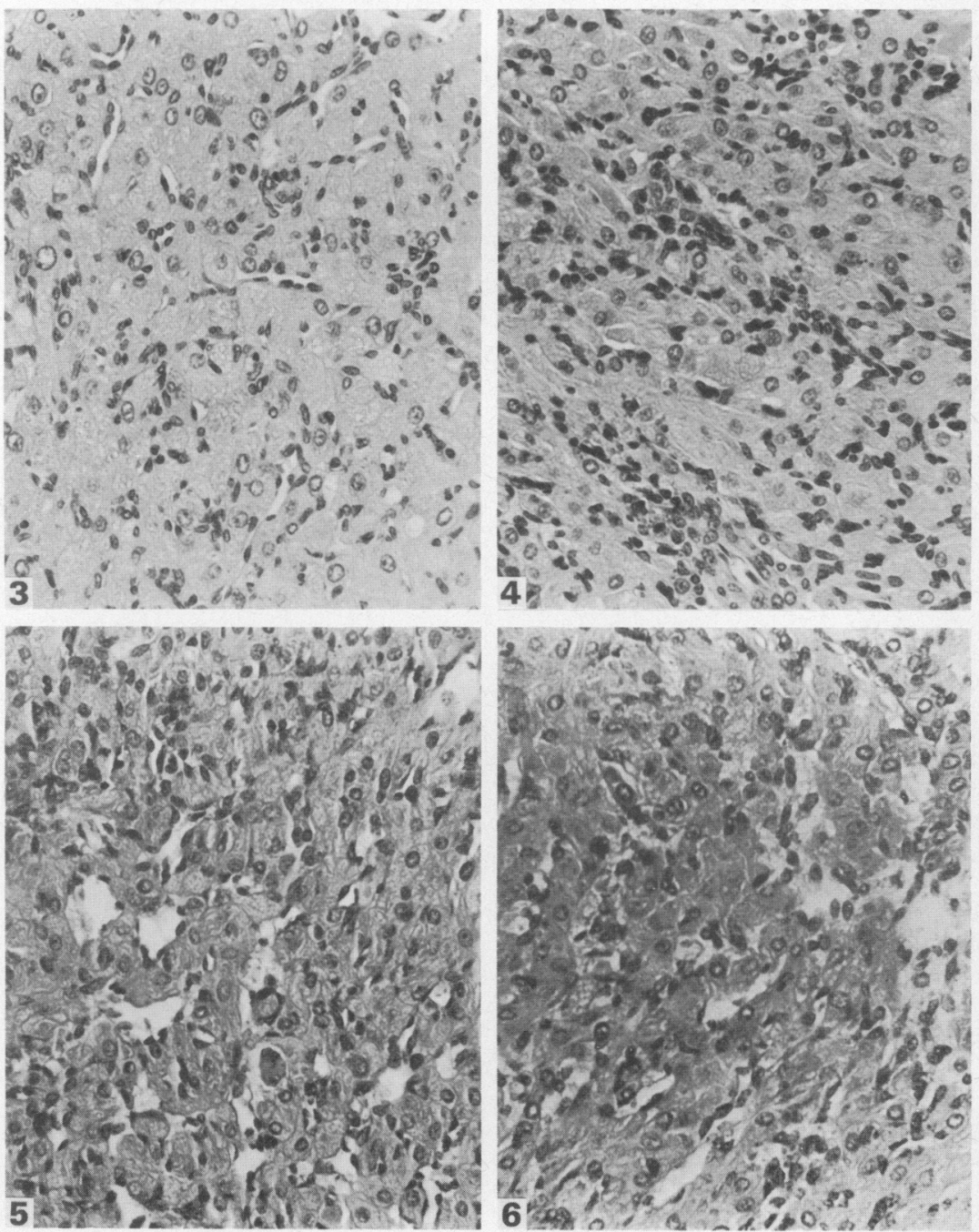
Blatchley et al. (1975) suggested that the extended luteal life-spans observed during pregnancy might result from suppression of oestradiol release. Our results suggest that suppression of oestrogen secretion is not the only factor involved in luteal maintenance, since exogenous oestrogen was not always effective in promoting rapid luteolysis. A change in the sensitivity of the pregnancy to oestrogen during gestation was shown in the present study.

We thank the staffs of the Departments of Animal Research and Histology for assistance and Professor J. T. France (National Women's Hospital, Auckland) for the gift of progesterone antiserum. The investigation was supported by grants from the N.Z. Medical Research Council and Foundation 41.

\section{References}

Bland, K.P. \& Donovan, B.T. (1969) Control of luteal function during early pregnancy in the guinea-pig. $J$. Reprod. Fert. 20, 491-501.

Blatchley, F.R., Maule Walker, F.M. \& Poyser, N.L. (1975) Progesterone, prostaglandin F2a and oestradiol in the utero-ovarian plasma of non pregnant and early unilaterally pregnant guinea-pigs. J. Endocr. 67, 225-229.

Challis, J.R.G., Heap, R.B. \& Illingworth, D.V. (1971) Concentrations of oestrogen and progesterone in the plasma of non-pregnant, pregnant and lactating guinea-pigs. J. Endocr. 51, 333-345.

Deanesly, R. (1963) Early embryonic growth and progesterone function in ovariectomized guinea-pigs. J. Reprod. Fert. 6, 143-152.

Feder, H.H., Resko, J.A. \& Goy, R.W. (1968) Progesterone concentrations in the arterial plasma of guinea pigs during the oestrous cycle. J. Endocr. 40, $505-513$.

Heap, R.B. \& Deanesly, R. (1966) Progesterone in systemic blood and placentae of intact and ovariec- tomized pregnant guinea-pigs. J. Endocr. 34, 417423.

Illingworth, D.V. \& Perry, J.S. (1973) Effects of oestrogen, administered early or late in the oestrous cycle, upon the survival and regression of the corpus luteum of the guinea-pig. J. Reprod. Fert. 33, 457-467.

Maule Walker, F.M. \& Poyser, N.L. (1974) Production of prostaglandins by the early pregnant guinea-pig uterus in vitro. J. Endocr. 61, 265-271.

Rowlands, I.W. (1956) The corpus luteum of the guinea-pig. Ciba Fdn Colloq. Ageing 2, 69-83.

Rowlands, I.W. \& Short, R.V. (1959) The progesterone content of the guinea-pig corpus luteum during the reproductive cycle and after hysterectomy. J. Endocr. 19, 81-86.

Tam, W.H. (1977) Steroid synthesis in vitro by the placenta of the guinea-pig and progesterone concentrations in systemic and uterine plasma. J. Endocr. 73, 473-489. 